\title{
Seasonal Microbial Quality of Drinking Water in Shendi Town, River Nile State, Sudan
}

\author{
Abdallah Ahmed Adam Belal ${ }^{1,2,{ }^{*}, \text { Basheer Mohammed El hassan }{ }^{3} \text {, Ahmed Mohammed Hussein }}{ }^{1,4}$ \\ ${ }^{1}$ Public Health Department, College of Health Sciences, Saudi Electronic University, Riyadh, Saudi Arabia \\ ${ }^{2}$ Environmental Health Department, Faculty of Public Health, Shendi University, Shendi, Sudan \\ ${ }^{3}$ Civil Engineering Department, Faculty of Engineering, University of Khartoum, Khartoum, Sudan \\ ${ }^{4}$ Public Health Department, Faculty of Public Health, Shendi University, Shendi, Sudan
}

Email address:

a.belal@seu.edu.sa (A. A. A. Belal), belalabdo011@ush.sd (A. A. A. Belal), abdallahahmed039@gmail.com (A. A. A. Belal)

${ }^{*}$ Corresponding author

\section{To cite this article:}

Abdallah Ahmed Adam Belal, Basheer Mohammed El hassan, Ahmed Mohammed Hussein. Seasonal Microbial Quality of Drinking Water in Shendi Town, River Nile State, Sudan. Journal of Health and Environmental Research. Vol. 7, No. 3, 2021, pp. 162-168. doi: $10.11648 /$ j.jher.20210703.17

Received: August 18, 2021; Accepted: September 2, 2021; Published: September 15, 2021

\begin{abstract}
The most common and widespread health risk associated with drinking water is microbial contamination which has the potential to cause large outbreaks of waterborne diseases. The objective of this study was to assess the bacteriological quality of drinking water in Shendi Town. A descriptive analytic study was used to examine the bacteriological quality of drinking water from sources, the distribution system, and household containers, Water samples were collected per season from all sources that used directly for drinking purpose in the community at study area according to the WHO Guidelines for drinking water quality. Water samples were examined for total coliforms, fecal coliforms, and E. coli by using (lauryl treptose media, brilliant green bile broth and peptone water (BGB), and Earthen methylene blue (EMB)) methods respectively. The study revealed that the bacteriological quality of drinking water varied from one season to another, where $31.3 \%$ of tested samples indicated feacal pollution in the summer season, and $41.3 \%$ of samples pointed to E. coli bacteria presence in autumn, While $36.3 \%$ of samples were appeared E. coli positive in the winter season. Based on the findings of this study we recommend that: Civil Water Corporation should be improvement the quality of currently drinking water by subjecting it to treatment processes, and must be established a surface drinking water treatment plant as soon as possible.
\end{abstract}

Keywords: Water Quality, Coliform Bacteria, Season Change, Pollution, Shendi Town, Indicator, Fecal Contamination

\section{Introduction}

Water is one of the basic requirements of human daily consumption, yet much of the world's population struggles to find consistent access to safe drinking water as recommended by the WHO drinking-water quality guidelines. Currently, about two billion people in the world live without access to safe drinking water $[1,2]$. Access to safe drinking water is one of the basic human rights and is enormously crucial to health. For a nation to maintain optimal health and development, there has to be a continual supply of safe drinking water to its population. However, drinking water is also the most important source of gastroenteric diseases worldwide, mainly due to the fecal contamination of raw water, failure in the water treatment process or recontamination of drinking water at source and point of use [3-8]. It is estimated that globally $80 \%$ of all illnesses are linked to use of unsafe and microbiologically poor water quality $[9,10]$.

The primary concern with health problems caused by water supply is infectious diarrheal diseases transmitted by the fecal- oral route, there for the principal concern in water quality is the microbiological quality of the water. Microbiological quality may change very rapidly over time and short distances, there for requires frequent testing [11, 12]. Water for drinking and cooking purposes must be made free from disease-producing organisms (pathogens), these organisms include viruses, protozoa, helminthes (worms), and bacteria. Some organisms, which cause diseases in 
people, originate with fecal discharge of infected individuals. Other are from the fecal discharge of animals [13]. Other organisms naturally present in the environment and not regarded as pathogens in drinking water may also cause occasional opportunist disease such as organisms in drinking water may cause infection predominantly among people whose local or general natural defense mechanisms are impaired, this is most likely to be the case in very old and young children, those organisms such as pseudomonas, flavor bacteria, acineto bacteria, klebsiella, and serratia [14].

Waterborne diseases are caused by a wide variety of pathogenic microorganisms, biotoxins, and toxic contaminants found in the water we drink, clean with, play in, and are exposed to through other less direct pathways such as cooling systems. Waterborne microorganisms include protozoa that cause cryptosporidiosis, parasites that cause schistosomiasis, bacteria that cause cholera and legionellosis, viruses that cause viral gastroenteritis, amoebas that cause amoebic meningoencephalitis, and algae that cause neurotoxicity [15]. The following groups of microorganisms have been linked with the occurrence of waterborne disease. As each pathogen is isolated and identified as a threat to water quality:

\subsection{Coli Form Group Bacteria}

Coli form bacteria defined here are as facultative an aerobic, gram negative, non-spore-forming rods that ferment lactose with gas formation within 48 hours at $35 \mathrm{deg}$. $\mathrm{C}$ or as applied to the membrane filter method a dark red colony with metallic sheen within 24 hours on an endo-type medium contain lactose. However an acrogenic (non gas producing) lactose fermenting strains of E. coli and coli forms that do not produce metallic sheen on endo medium may be encountered. These organisms as well as typical coli forms can consider indicator organisms [16]. Fecal coli form bacteria more than $99 \%$ of which are E. coli are an indicator of the level of human /animal waste contamination in water and the possibility of presence of harmful pathogen i.e. microbiological contamination. It is worth noting that sometimes the presence of coli form organisms (total coli form) is used as an indicator. However coli form organism may not always be directly related to the presence of fecal contamination or pathogens in drinking water, but still the coli form test used for monitoring the microbial quality of the treated piped water supplies [17]. The indicator bacteria that most surveillance bodies use in routine assessment of risk of fecal contamination is Escherichia coli (E. coli) or as an alternative thermo tolerant coli form. E. coli provides the closest match to criteria for an ideal indicator, however it is not perfect and it is possible to find pathogens in drinking water supplies when E. coli is absent. Basic characteristics of the ideal indicator are: Present wherever pathogens are present, present in the same of higher numbers than pathogens, specific for fecal or sewage pollution, at least as resistant as pathogens to conditions in natural water environments and water purification and disinfection process, none pathogen [11]. The second edition of the WHO guide lines for drinking water quality published in 1993 strongly recommended the use of $\mathrm{E}$. coli as the preferred fecal indicator because its provides the closest match to the criteria for an ideal indicator [18].

\subsection{Escherichia Coli Pathogenic Strains}

Escherichia coli is present in large numbers in normal intestinal flora of humans and animals, where it's generally causes no harm. However in other parts of the body E. coli can cause serious diseases such as urinary tract infections, bacteraemia and meningitis. A limited number of entero pathogenic strains can cause acute diarrhea. Several classes of entero pathogenic E. coli have been identified on the basis of different virulence factors, including entero hemorrhagic E. coli (EHEC), entero toxinogenic E. coli (ETEC), entero pathogenic E. coli (EPEC), entero invasive E. coli (EIEC), entero aggregative E. coli (EAEC), and diffusely adherent E. coli (DAEC). EHEC organisms can cause infections, ETEC produces heat labile or heat stable E. coli entero toxin, or both toxin simultaneously and is an important cause of diarrhea in developing countries specially in young children, infection with EPEC has associated severe, chronic, non bloody diarrhea, vomiting and fever in infants, this occur commonly in developing countries and rare in developed counties. EIEC causes watery and occasionally bloody diarrhea. Entero pathogenic E. coli are I enteric organisms and humans are the major reservoir, particularly of EPEC, ETEC, and EIEC strains. Lives stock such as cattle, sheep, goats, pigs, and chickens are major [19].

\subsection{Thermo Tolerant Bacteria}

Thermo tolerant coli form bacteria are coli form organisms that are able to ferment lactose at $44-45 \mathrm{deg}$. C., the group include the genus E. coli and some species of klebsiella, Entero bacter and citro bacter. Because thermo tolerant coli form organisms are readily detected they have an important secondary role as indicators of the efficiency of water treatment process in removing fecal bacteria [19].

\section{Materials and Methods}

\subsection{Study Design}

A descriptive analytic study.

\subsection{Study Area}

Shendi Town is well known historically, and it is the third largest Town in River Nile State. It is in River Nile State, where the Headquarter of Shendi locality is located.

Shendi is located about $176 \mathrm{~km}$ north of Khartoum , and $130 \mathrm{~km}$ south of El damer (capital of River Nile State). It is bound by River Nile in the west and Kasala State in the East, also bound by south Shendi administrative unit in the South and Shendi administrative unit in the North. Geographically it lies between line 36 East to 31 West longitudinal and line 19 North to 15 South latitudinal. It is in the arid zone of Sudan with annual rain fall ranging between 0 and $119 \mathrm{~mm}$ per year. Shendi town has no sewerage system, the population depend on septic tanks, aqua privies, pour flush latrines and traditional 
pit latrines for disposal of fecal waste and other liquid waste. Shendi town has a distribution system of drinking water; the whole Town depends on ground water as source of drinking.

\subsection{Study Population}

Water sources, water supply system and household facilities.

\subsection{Sample Size Determination}

Samples for bacteriological analysis were determined according to WHO guidelines (one sample for each 5000 of population monthly, total population of Shendi Town is 97486 so sample size $=97486 / 5000=19.5 \approx 20$ for a year $n$ $=20 * 12$ equal 240 samples.

\subsection{Water Sample Collection}

Water samples were collected according to the WHO Guidelines for drinking water quality assessment [20, 21]. The samples were collected from ground water sources (wells), distribution system and storage facilities, that are used directly for drinking purpose in the community per seasons. Closed sterilized $500 \mathrm{ml}$ glass containers were used to collect samples aseptically. Before taking sample from wells, pipes and taps, the pipes water was flushed for $5 \mathrm{~min}$ and then the mouth of the pipe and tap was sterilized with a spirit of lamp flame and then cooled by running water. Sample from hand dung wells were collected by attaching a piece of string to the sampling bottle together with a clean heavy material that sink down the bottle into the well and unwinding the string slowly. Stored water samples were collected after 1 to $3 \mathrm{~h}$ of storage using the usual cups households use to draw the water from the storage container. All samples were transported to the laboratory on ice box, kept at $4{ }^{\circ} \mathrm{C}$ and analyzed within $4 \mathrm{~h}$. The samples were drawn for three seasons (summer 2014, autumn 2014 and winter 2015).

\subsection{Microbiological Analysis}

Microbiological analyses of water samples were performed as described in Standard Methods for the Examination of drinking water [22, 23]. Total and fecal coliforms were determined by the presence - absence (P-A) per $100 \mathrm{ml}$ sample using (lauryl treptose media) And Put the bottle somewhere with a constant temperature $\left(25-35^{\circ} \mathrm{C}\right)$ for 24 to 48 hours. Then Checked the bottle after 24 hours to see if there is a colour change. If there is no colour change, then let the bottle for another 24 hours. For samples which gave positive results for coliforms test, further identification was done by inoculated in brilliant green bile broth and peptone water, all samples were incubated at $44^{\circ} \mathrm{C}$ for 24 hours, any sample that shows colour change (red ring) and gas production is positive for coliform presence truly. For isolation E. coli, all positive results of previous test were taken and Each sample was cultured on Earthen methylene blue (EMB) media in petri dish and all petri dishes were incubated at $37^{\circ} \mathrm{C}$ for 24 hours. Then any sample that shows green metallic shine colonies are E. coli presence.

\subsection{Data Analysis}

Data were analyzed by computer using both Microsoft Excel and Microsoft word, and then the results are presented in percentage tables and other statistical graphs.

\section{Results}

Table 1. Bacteriological analysis for water samples in summer season.

\begin{tabular}{|c|c|c|c|c|c|c|c|}
\hline \multirow{2}{*}{ Sampling location } & \multirow{2}{*}{$\begin{array}{l}\text { Number of tested } \\
\text { samples }\end{array}$} & \multicolumn{2}{|c|}{ Total Coliform Test /lauryl } & \multicolumn{2}{|c|}{ Thermo-tolerant Test/ BGB } & \multicolumn{2}{|c|}{ E.coli Test/EMB } \\
\hline & & + & - & + & - & + & - \\
\hline Sources (Wells) & 20 & 19 & 1 & 16 & 3 & 8 & 8 \\
\hline Storage facilities & 21 & 18 & 3 & 15 & 3 & 5 & 10 \\
\hline Distribution system & 39 & 33 & 6 & 27 & 6 & 12 & 15 \\
\hline Total & 80 & 70 & 10 & 58 & 12 & 25 & 33 \\
\hline
\end{tabular}

Key

$+\mathrm{VE}$

Positive / Presence
$-\mathrm{VE}$

Negative /Absence

The above table shows that $31.3 \%$ of samples are indicated presence of feacal pollution.

Table 2. Bacteriological analysis for water samples in autumn season.

\begin{tabular}{|c|c|c|c|c|c|c|c|}
\hline \multirow{2}{*}{ Sampling location } & \multirow{2}{*}{$\begin{array}{l}\text { Number of tested } \\
\text { samples }\end{array}$} & \multicolumn{2}{|c|}{ Total Coliform count Test /lauryl } & \multicolumn{2}{|c|}{ Thermo-tolerant count Test/ BGB } & \multicolumn{2}{|c|}{ E.coli count Test/EMB } \\
\hline & & + & - & + & - & + & - \\
\hline Sources (Wells) & 18 & 18 & 0 & 16 & 2 & 7 & 9 \\
\hline Storage facilities & 23 & 23 & 0 & 21 & 2 & 12 & 9 \\
\hline Distribution system & 39 & 39 & 0 & 35 & 4 & 14 & 21 \\
\hline Total & 80 & 80 & 0 & 72 & 8 & 33 & 39 \\
\hline
\end{tabular}

Key

$+\mathrm{VE}$

Positive / Presence
$-\mathrm{VE}$

Negative /Absence 
The above table shows that $31.3 \%$ of samples are indicated presence of feacal pollution.

Table 3. Bacteriological analysis for water samples in winter season.

\begin{tabular}{lllllll}
\hline \multirow{2}{*}{ Sampling location } & Number of tested & \multicolumn{2}{l}{ Total Coliform count Test /lauryl } & \multicolumn{2}{l}{ Thermo-tolerant count Test/ BGB } & E.coli count Test/EMB \\
\cline { 2 - 6 } & samples & + & - & + & - & + \\
\hline Sources (Wells) & 17 & 17 & 0 & 16 & 1 \\
Storage facilities & 28 & 27 & 1 & 25 & 2 & 8 \\
Distribution system & 35 & 34 & 1 & 30 & 4 & 10 \\
Total & 80 & 78 & 2 & 71 & 7 & 29 \\
\hline
\end{tabular}

Key

$+\mathrm{VE}$

Positive / Presence

-VE

Negative /Absence

The above table shows that $36.3 \%$ of samples are indicated presence of feacal pollution.

Table 4. Bacteriological quality for drinking water samples per seasons.

\begin{tabular}{llll}
\hline Season & NO of tested samples & E. coli positive & Percentage\% \\
\hline Summer & 80 & 25 & 31.3 \\
Autumn & 80 & 33 & 41.3 \\
Winter & 80 & 29 & 36.3 \\
Total & 240 & 87 & 36.3 \\
\hline
\end{tabular}

The above table shows that the highest pollution in autumn season $41.3 \%$ and then in winter season $36.3 \%$.

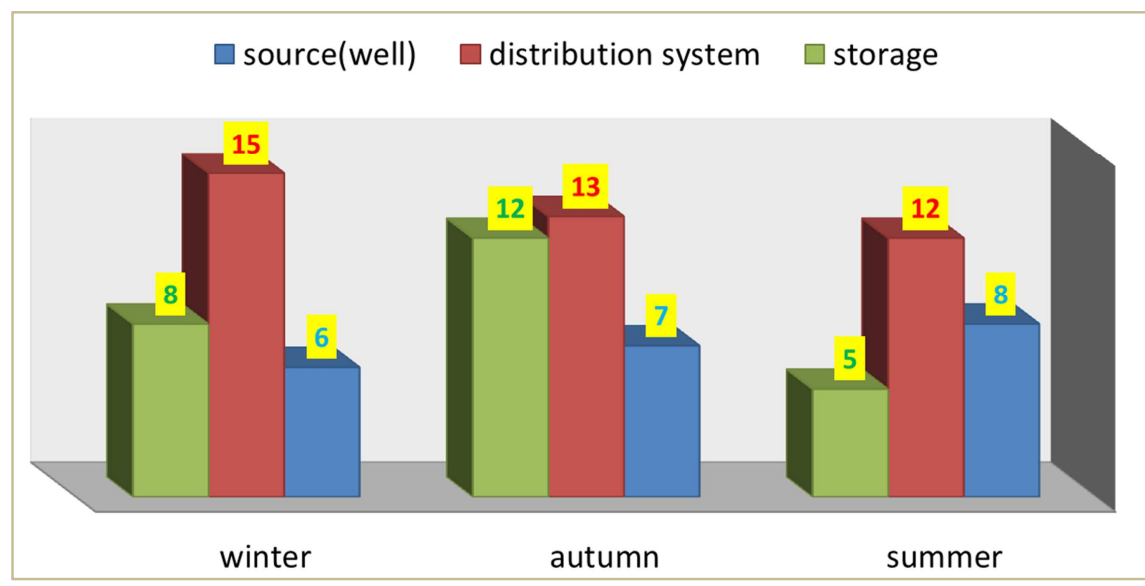

Figure 1. Comparison of polluted samples per seasons.

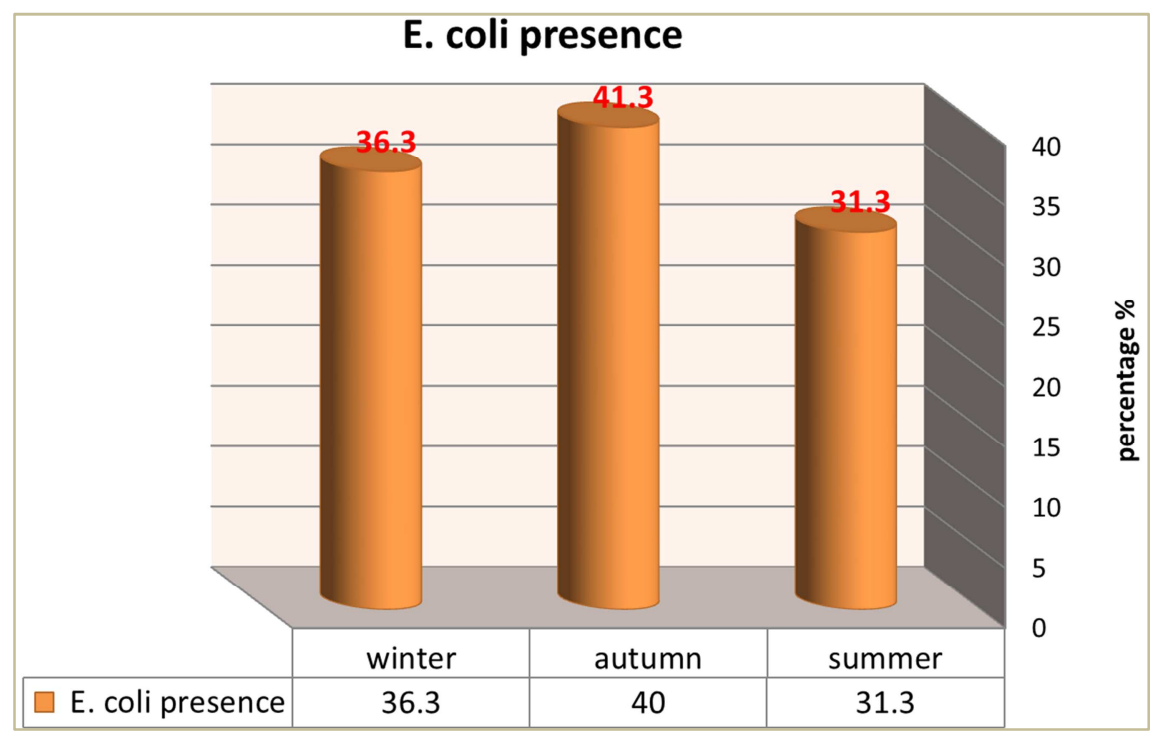

Figure 2. Comparison of E. coli presence per seasons. 
The above figure shows that $36.3 \%, 41.3 \%, 31.3 \%$ of tested samples are E. coli positive and the highest ratio in autumn season $(41.3 \%)$.

\section{Discussion}

Water is essential to life, access to safe and adequate water is important to human health. Providing safe and clean water is a basic norm in developed countries but many people, especially in developing countries, struggle to get access to safe water $[24,25]$. Detection of certain groups of bacteria acts as an indicator for fecal contamination. The most widely used indicator groups are Total coliform, E. coli, and Enterococci [26].

Unsafe drinking water is one of the basic health problems in Sudan. The study revealed that the bacteriological quality of drinking water varied from one season to another, where $31.3 \%$ of tested samples indicated feacal pollution in the summer season, (table 1). And $41.3 \%$ of samples pointed to E. coli bacteria presence in autumn, (table 2). While 36.3\% of samples were indicated E. coli positive in winter (tables 3,). All indicators of bacteriological quality are above guidelines of WHO and SSMO (Sudanese Standards Metrology Organization), all water intended for drinking E. coli or thermo tolerant coli form must not detectable in any $100 \mathrm{mg} / 1$ sample, treated water entering distribution system E. coli, thermo tolerant coli form bacteria must not be detectable in any $100 \mathrm{mg} /$ sample, in the case of a large supplies system when sufficient samples were examined E. coli bacteria must not be detectable in $95 \%$ of samples (SSMO) [27-30].

Although the WHO guideline for drinking water does not allow any detection of fecal coliforms and E. coli, our study showed that feacal pollution was found in all seasons but in autumn is higher than in other seasons,(Figure 2), this may be due to the absence of sewerage system in Shendi Town and runoff during rainfall, also raise of level of water in aquifer or water table, especially during the period of study in 2014 heavy rains were precipitated in the study area, so according to these results, the quality of water is not suitable for drinking without appropriate treatment process. In a previous study conducted by Amera and Saad (2012), in North Kordofan state to identify seasonal variation effects on drinking water quality, they found that bacteriological quality of water is very poor with the very high level of E. coli and feacal coli form count in most seasons. With a peak in the rainy season. Also in another past study conducted by Mohammed (2009), to assess bacteriological quality of drinking water in West Kordofan state, he revealed that all samples pointed to an extremely high level of total coli forms were detected at each sample. The researchers revealed that the highest count of pollution was seen in autumn compared to other seasons, this is typical as the results revealed by the present study. While in another previous study done by Hamza (2011), in Elobiet Town, he found that there are bacteriological contamination in the water supply system in all three seasons but the highest one in the summer season and then autumn, where $94 \%, 81 \%$, and $23.6 \%$ of tested samples were positive coli forms, thermo tolerant and E. coli respectively. Also in another past study conducted by Mohmmed (2012), in Kosti Town, he reported that high growth of total coli forms bacteria, in all samples $100 \%$ were positive for coli forms and thermotolerant bacteria, the study pointed that seasonal variations with regard E coli presence, where $89.7 \%, 76.9 \%$ and $66.7 \%$ off samples were positive in summer, rainy and winter respectively.

The present study showed that drinking water pollution was detected in all sites of sampling (well, the distribution system and storage facilities) while it is more in samples of the distribution system (figure 1) so the distribution system in Shendi Town needs urgent interventions from related authorities. these results are in agreement with Eltigani (2007) in a previous study conducted in Shendi locality to investigate bacteriological quality in drinking water, he found that thirteen out of $48(27.1 \%)$ samples collected from different sources of drinking water were contaminated with E. coli bacteria, the highest contamination due to E. coli presence in the distribution system, storage facilities then shallow well and surface sources respectively. In a previous study done by Othman, Hamid, and Ali (2010), to assess the bacteriological quality of groundwater in the west Omdurman area in eight sites, they found that the presence of feacal coli forms bacteria in seven sites, the researchers said the reason return to the public sanitation system.

\section{Conclusion}

Based on the findings of this study the following conclusions are drawing: - the indicator of water pollution (E. coli bacteria) was detected in all seasons, with highest level in autumn and it's above than the admissible level of WHO and Sudanese standards for drinking water in all seasons especially in rain fall season. Therefor the drinking water quality microbiologically is poor and not fit for drinking purpose without appropriate method of treatment.

\section{Recommendations}

For healthy living, potable safe water is absolutely essential. It is a basic need for all human beings to get an adequate supply and pure drinking water. So based on the findings of this study we recommend that: Civil Water Corporation should be improving the quality of currently drinking water by subjecting it to treatment processes, and must be established a surface drinking water treatment plant as soon as possible.

\section{Conflict of Interests}

The authors have not declared any conflict of interests. 


\section{Funding}

This research did not receive any specific grant from funding agencies in the public, commercial, or not-for-profit sectors.

\section{Acknowledgments}

The authors acknowledge the family of the Federal Ministry of Health (Environmental health and food control directorate) for their administrative help. Also, we would like to thank the family of the Ministry of Health- River Nile state (Environmental health and food control department) for providing laboratory facilities. We send many thanks to all those who are supported, contributed, and helped us in this study.

\section{References}

[1] WHO (World Health Organization) (2017a). News Release, World Health Organization, Geneva. Available from: www.who.int/news-room/detail/12-07-2017-2-1-billionpeople-lack-safe-drinking-water-at-home-more-thantwice-asmany-lack-safe-sanitation (accessed 1 January 2019).

[2] WHO (World Health Organization) (2017b). Guidelines for Drinking-Water Quality, ${ }^{\text {th }}$ edn. World Health Organization, Geneva.

[3] WHO (World Health Organization) (2003). Guidelines for Drinking Water Quality, Geneva, Switzerland, $3^{\text {rd }}$.

[4] Pironcheva V (2004). Water Management Practices in Rural and Urban Homes: A Case of Bangladesh on Ingestion of Polluted Water. J. Public Health 112: 317-321.

[5] Wright J, Gundry S, Conroy R. (2004). Household drinking water in developing countries: a systematic review of microbiological contamination between source and point-ofuse. Trop. Med. Int. Health 9 (1): 106-117.

[6] Clasen T, Nadakatti S, Menon S (2006). Microbiological performance of a water treatment unit designed for household use in developing countries. Trop. Med. Int. Health 11 (9): 1399-1405.

[7] Clasen T, Schmidt WP, Rabie T, Roberts I, Cairncross S (2007). Interventions to improve water quality for preventing diarrhea: systematic review and meta-analysis. BMJ. 334 (7597): 782.

[8] Miner CA, Dakhin AP, Zoakah Al, Zaman M, Bimba J (2016) Physical and Microbiological Quality of Drinking Water Sources in Gwafan Community, Plateau State, Nigeria. Pyrex J. Res. Environ. Stud. 3 (1): 001-006.

[9] WHO (World Health Organization) (2002). Guide lines for drinking water standards in developing countries, pan American health organization, Regional office of the world health organization, Lima.

[10] WHO (World Health Organization) (2002). Reducing risks, promoting Healthy life, Geneva, Switzerland.

[11] Mpenyana-Monyatsi L, Onyango MS, Momba MNB (2012). Groundwater quality in South African Rural Community: a
Possible Threat to Public Health. Pol. J. Environ. Stud. 21 (5): 1349-1358.

[12] Howard A. G. (2002). Water supply surveillance. A reference manual WEDC, lough borough university, UK.

[13] Howard A. G. (2002). Water quality surveillance, a practical guide, WEDC, lough borough university, UK.

[14] Davis M. L. and Cornwell D. A. (1998). Introduction to environmental engineering. International edition, $3^{\text {rd }}$ ed., Singapore.

[15] WHO (World Health Organization) (1984). Guidelines for drinking Water Quality, World Health Organization Press.

[16] Bartram, J. K, Fisher, M. B., Williams, A. R., Jalloh, M. F., Saquee, G., and Bain, R. E. S. (2015). Microbiological and chemical quality of packaged sachet water and household stored drinking water in Freetown, Sierra Leone. PLoS One 10, 1-17. doi: 10.1371/journal.pone.0131772.

[17] APHA, AWWA and WEF (1998). Standards methods for the examination of water and waste water, $20^{\text {th }}$ ed., Washington.

[18] Oxfam (2001). Guide lines for water treatment in emergencies, Oxfam humanitarian department (new Oxfam logo), Oxford.

[19] WHO (World Health Organization) (1997). Guide lines for drinking water quality, volume 3 , surveillance and control of community supplies, $2^{\text {nd }}$ ed., Geneva.

[20] WHO (World Health Organization) (1993). Global strategy: Health, Environmental and Development. Approaches to drafting countrylevel strategies for human well being under Agenda 21. WHO Document, Geneva Switzerland.

[21] WHO (World Health Organization) (1993). Guide lines for drinking water quality in distribution system, volume one, Geneva.

[22] WHO (World Health Organization) (1996). Guidelines for drinking water quality: Health criteria and other are supporting information, Geneva Switzerland, 2nd edition.

[23] APHA (2005). Standard methods for the examination of water and waste water. $21^{\text {th }}$ ed. Washington, DC.

[24] Prüss-Ustün, A., Bartram, J., Clasen, T., Colford, J. M., Cumming, O., Curtis, V., et al. (2014). Burden of disease from inadequate water, sanitation and hygiene in low- and middleincome settings: A retrospective analysis of data from 145 countries. Trop. Med. Int. Heal. 19, 894- 905. doi: 10.1111/tmi.12329.

[25] Alves, R. I. S., Machado, C. S., Beda, C. F., Fregonesi, B. M., Nadal, M., Sierra, J., et al. (2018). Water Quality Assessment of the Pardo River Basin, Brazil: A Multivariate Approach Using Limnological Parameters, Metal Concentrations and Indicator Bacteria. Arch. Environ. Contam. Toxicol., 1-14. doi: 10.1007/s00244-017-0493-7.

[26] Saxena, G., Bharagava, R. N., Kaithwas, G., and Raj, A. (2015). Microbial indicators, pathogens and methods for their monitoring in water environment. J. Water Health 13, 319339. doi: 10.2166/wh.2014.275.

[27] WHO (World Health Organization)(2004). Water treatment and pathogen control, process efficiency in achieving safe drinking water, first published printed by $\mathrm{Tj}$ international (Ltd), Dad stow, cornwall, UK. 
[28] WHO (World Health Organization) (2004). Guidelines for drinking-water quality. Third edition. Volume 1 Recommendations. Geneva, World Health Organization.

[29] WHO (World Health Organization)(2006). Guide lines for drinking water quality, volume 1 , a first addendum (recommendations), $3^{\text {rd }}$ ed., Geneva.
[30] SSMO (Sudanese Standards Metrology Organization (2002). Drinking water guide lines, first edition, republic of Sudan, March 2002, Khartoum. 